\title{
Body concentration of caesium-137 in patients from Western Isles of Scotland
}

\author{
C G Isles, I Robertson, J A J Macleod, T Preston, B W East, D J Hole, A F Lever
}

\begin{abstract}
Objectives - To compare caesium-137 concentrations in patients from the Western Isles Health Board, Glasgow area, and other parts of the Scottish mainland, and to investigate the source of ${ }^{137} \mathrm{Cs}$ in patients from the Western Isles.

Design-Study of hypertensive patients having electrolyte concentrations measured, including ${ }^{137} \mathrm{Cs}$. Interview by questionnaire of island subjects about intake of foods likely to contain radiocaesium and the source of these foods. Measurement of ${ }^{137} \mathrm{Cs}$ and ${ }^{134} \mathrm{Cs}$ in food, urine, and vegetation.

Setting-Scottish mainland and Western Isles, 1979-86. All measurements before Chernobyl nuclear accident.
\end{abstract}

Patients -413 consecutive patients referred to the blood pressure unit for investigation of hypertension. 60 from the Western Isles, including 44 from North Uist; 32 from North Uist participated in the dietary analysis.

Main outcome measures - Concentration of radiocaesium in the body, urine, food, and vegetation. Islanders' consumption of local produce.

Results-Patients from the Western Isles had five times higher body concentrations of ${ }^{137} \mathrm{Cs}$ (median 2.54 (interquartile range $1 \cdot 25-3.73)$ ) $\mathrm{Bq} / \mathrm{gK}$ ) than did patients from around Glasgow $(0.47(0.26-0.66)$ $\mathrm{Bq} / \mathrm{gK})$ and other parts of the Scottish mainland $(0.42(0.24-0.71) \mathrm{Bq} / \mathrm{gK})$. Islanders often consumed local milk and mutton, but ate local fish rarely. ${ }^{137} \mathrm{Cs}$ and ${ }^{134} \mathrm{Cs}$ were present in coastal $\left(21.6 \mathrm{~Bq} / \mathrm{kg}{ }^{137} \mathrm{Cs}\right.$, $\left.0.25 \mathrm{~Bq} / \mathrm{kg}{ }^{134} \mathrm{Cs}\right)$ and moorland $(135.9,0.65 \mathrm{~Bq} / \mathrm{kg})$ grasses and in islanders' urine $(2.01,0.013 \mathrm{~Bq} / \mathrm{l})$. Lower concentrations $(0.336,0.004 \mathrm{~Bq} / \mathrm{l})$, were found in the urine of Glasgow controls $(p<0.001$ for both isotopes).

Conclusions-Islanders have excess body ${ }^{137} \mathrm{Cs}$ concentrations, most of which probably comes from local milk and lamb. The radioactivity is not above the recommended safety limit. The presence of ${ }^{134} \mathrm{Cs}$ suggests that nuclear reprocessing is the source of some of the radiocaesium.

\section{Introduction}

Whole body concentrations of caesium-137 are closely related to dietary intake of the isotope, ${ }^{1}$ which has a physical half life of 30 years but a biological half life of only 110 days in man. ${ }^{2}$ It is distributed widely throughout the body and is excreted mainly in urine. ${ }^{2}$ Before the explosion of the Chernobyl nuclear reactor, ${ }^{137} \mathrm{Cs}$ in humans came mainly from fallout from nuclear weapons testing. ${ }^{1}$ In 1981 Williams et al reported high concentrations of body ${ }^{137} \mathrm{Cs}$ in five patients from the Western Isles and suggested that fish contaminated with radiocaesium from the Sellafield nuclear fuel reprocessing plant was the main source. ${ }^{3}$ Their conclusion was contested. ${ }^{4}$

We measured ${ }^{137} \mathrm{Cs}$ concentrations in Scottish patients and examined their diet to confirm the existence of higher body ${ }^{137} \mathrm{Cs}$ concentrations in island

patients and to determine the source of the excess.
Preliminary accounts of this work have been published. ${ }^{56}$

\section{Subjects and methods}

We studied 413 consecutive patients attending the blood pressure unit in Glasgow during 1979-86, all of whom had ${ }^{137} \mathrm{Cs}$ body concentrations measured at the Scottish Universities Research and Reactor Centre, East Kilbride. There were 243 men (mean age 45 years, range 18-72) and 170 women (46, 20-79). Most patients (218) lived in the Glasgow area, 101 in other parts of mainland Scotland, 25 in England, seven in Ireland, and two overseas. Sixty patients were from the Western Isles: $\mathbf{4 4}$ from North Uist, seven from Lewis, five from South Uist, and one each from Barra, Skye, Raasay, and Mull.

Most patients from Glasgow and all patients from the Western Isles were referred directly by their general practitioners for investigation of uncomplicated essential hypertension. The large number from North Uist reflects an interest of one of the authors (JAJM) in cardiovascular disease. Patients from other parts of the United Kingdom and overseas tended to have more complex disease and had been referred by hospital doctors.

\section{MEASUREMENT OF BODY ${ }^{137} \mathrm{CS}$ CONCENTRATIONS}

Patients underwent whole body composition analysis, primarily to assess their total body content of sodium and potassium. ${ }^{78} \mathrm{As} \mathrm{s}^{137} \mathrm{Cs}$ and potassium- 40 are both gamma emitters ${ }^{137} \mathrm{Cs}$ concentration was determined when measuring ${ }^{40} \mathrm{~K}$ and before the activation analysis needed to measure sodium. Radiocaesium concentrations are expressed in relation to potassium concentration. The whole body counter consisted of two large sodium iodide detectors mounted within a lead shield, and the method of measuring ${ }^{137} \mathrm{Cs}$ activity has been described. ${ }^{910}$ Permission to undertake the body composition study was obtained from Western Infirmary ethics committee and from the Administration of Radioactive Substances Advisory Committee. All measurements were made before the Chernobyl accident in 1986.

\section{DIETARY ASSESSMENT OF ISLANDERS}

We obtained dietary histories in May 1984 from the 32 patients from North Uist - all those who had been investigated in Glasgow up until that time. Islanders completed a questionnaire on their intake of milk, meat, fish, and other foods and were asked whether their food was produced locally or imported and how often each item was consumed. Demographic details were also recorded.

${ }^{137} \mathrm{CS}$ AND ${ }^{134}$ CS CONCENTRATIONS IN FOOD, URINE, AND ENVIRONMENT

Samples of the urine of islanders together with island milk, lamb, fish, vegetables, seaweed, herbage, and tidal sediments were collected and screened by rapid high sensitivity gamma ray counting to determine ${ }^{137} \mathrm{Cs}$ concentrations. The results were compared with those
Medicine, Royal Infirmary, Dumfries DG1 4AP.

BM于 1991;302:1568-71 
from similar products bought in the Glasgow area and with published reports of ${ }^{137} \mathrm{Cs}$ concentrations in foods from other parts of Britain. ${ }^{112}$ We then examined selected samples with high ${ }^{137} \mathrm{Cs}$ concentrations by high resolution gamma ray spectrometry using both germanium-lithium and pure germanium detectors (E G and $\mathrm{G}$ Ortec) to obtain ${ }^{137} \mathrm{Cs}$ and ${ }^{134} \mathrm{Cs}$ values. ${ }^{134} \mathrm{Cs}$ was measured because the isotope is produced by reprocessing nuclear fuel but not by explosion of nuclear weapons.

Because concentrations of ${ }^{134} \mathrm{Cs}$ were low we collected and concentrated large samples and, where necessary, counted for up to 96 hours. Grasses were concentrated by drying and ashing. Urine samples of up to 151 were obtained from 12 patients from North Uist and from 12 Glasgow controls (six hypertensive and six normotensive), and radiocaesium was extracted on to potassium hexacyanocobalt ferrate. ${ }^{13}$ Recovery of added radioactivity was greater than $95 \% .{ }^{14} \mathrm{~A}$ similar extraction procedure was used for milk but with smaller volumes. Food samples up to 11 were counted without being concentrated.

We corrected observed sample counts for counter background detector efficiency and yield of gamma rays, the background being determined at intervals arranged to bracket groups of samples. The limit of detection for ${ }^{134} \mathrm{Cs}$ (taken as three standard deviations of background count) was $0 \cdot 1 \mathrm{~Bq}$ for samples $\leqslant 11$ and $0.04 \mathrm{~Bq}$ for the concentrated urine samples, for which geometrical counting efficiency was better.

\section{STATISTICAL METHODS}

Because most of the data were not normally distributed we have used median values throughout. Comparisons are made by the Mann-Whitney U test. The time trend data in figure 1 were analysed by linear regression with a logarithmic scale.

\section{Results}

Patients from the Western Isles had five times higher concentrations of ${ }^{137} \mathrm{Cs}$ than did those from other areas (table I). Concentrations higher than $2 \mathrm{~Bq} / \mathrm{gK}$ were found in 35 of 60 islanders but in only one of 218 Glaswegians. The patient with the highest value $(8.53 \mathrm{~Bq} / \mathrm{gK})$ lived in Stornoway, Lewis.

Body ${ }^{137} \mathrm{Cs}$ concentrations were slightly higher in men than in women (median 0.49 and $0.38 \mathrm{~Bq} / \mathrm{gK}$ respectively, excluding patients from the Western Isles). Patients with primary hyperaldosteronism had higher radiocaesium to potassium ratios than did those with essential hypertension (table I) because of lower concentrations of potassium rather than higher concentrations of caesium. However, only one of the 22 patients with primary hyperaldosteronism was an islander. Mean body potassium concentration of the islanders was $105.6 \%$ of predicted normal value; concentrations $104 \%$ of normal have been reported in patients with essential hypertension. ${ }^{7}$ Thus high ratios of body ${ }^{137} \mathrm{Cs}$ to ${ }^{40} \mathrm{~K}$ in islanders were probably not due

TABLE I - Body concentration of caesium-137 according to place of residence and underlying disease

\begin{tabular}{|c|c|c|c|c|}
\hline & $\begin{array}{c}\text { No of } \\
\text { subjects }\end{array}$ & $\begin{array}{c}\text { Median } \\
\text { (interquartile } \\
\text { range) }{ }^{137} \mathrm{Cs} \\
(\mathrm{Bq} / \mathrm{gK})\end{array}$ & $\begin{array}{c}\text { Difference } \\
\text { Mann-Whitney } \\
\text { U }\end{array}$ & $\mathrm{p}$ Value \\
\hline \multicolumn{5}{|l|}{ Place of residence: } \\
\hline Western Isles & 60 & $2.54(1.25$ to 3.73$)$ & & \\
\hline Glasgow & 218 & $0.47(0.26$ to 0.66$)$ & $700 \cdot 5$ & $<0.001$ \\
\hline Other parts of Scottish mainland & 101 & $0.42(0.24$ to 0.71$)$ & $389 \cdot 0$ & $<0.001$ \\
\hline England & 25 & $0.46(0.22$ to 0.70$)$ & $99 \cdot 0$ & $<0.001$ \\
\hline Underlying disease (excluding subjects in Western Isles): & & & , & \\
\hline Essential hypertension & 167 & $0.46(0.28$ to 0.62$)$ & & \\
\hline Renovascular disease & 35 & $0.47(0.31$ to 0.70$)$ & $2676 \cdot 5$ & 0.43 \\
\hline Primary hyperaldosteronism & 22 & $0.68(0.38$ to 0.81$)$ & $1389 \cdot 5$ & 0.06 \\
\hline Other & 129 & $0.40(0.20$ to 0.66$)$ & $9764 \cdot 0$ & $0 \cdot 17$ \\
\hline
\end{tabular}

Caesium concentrations are expressed in relation to body concentration of potassium.

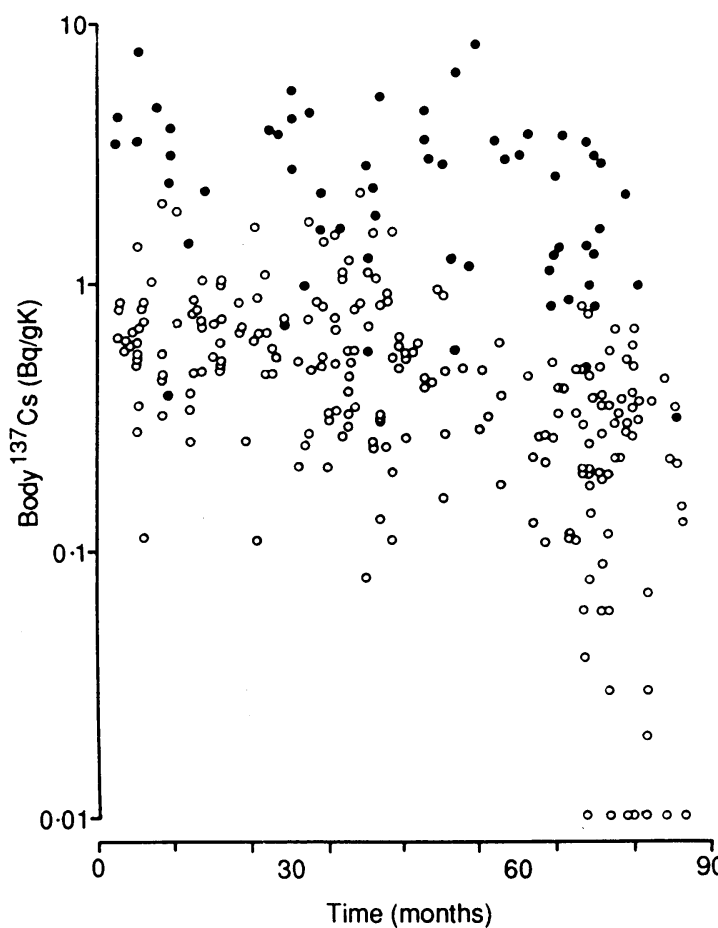

FIG $1-$ Body concentrations of caesium-137 in 60 patients from Western Isles ( $\bullet$ ) (gradient $=-0.0053, t=-3.52, p<0.001$ by linear regression on log scale) and 218 from Glasgow area $(0)$ (gradient $=-0.008, t=-8.72, p<0.001$ ) during 1979-86. All measurements taken before Chernobyl accident

to low potassium or high aldosterone concentrations.

${ }^{137} \mathrm{Cs}$ concentrations fell significantly during $1979-86$ in both islanders $(p<0.001)$ and patients from the Glasgow area $(p<0.001)$ (figure). Discharges of ${ }^{137} \mathrm{Cs}$ from Sellafield into the Irish Sea and fallout of ${ }^{137} \mathrm{Cs}$ also fell during the study (table II). ${ }^{15} 16$ Regional differences in fallout usually relate to differences in rainfall, but there were no large differences in rainfall in the Western Isles (Benbecula) and the Glasgow area (table II).

TABLE II-Discharges of radiocaesium from Sellafield reprocessin plant and rainfall in Western Isles and Glasgow, 1978-1985

\begin{tabular}{|c|c|c|c|c|c|}
\hline \multirow[b]{2}{*}{ Year } & \multicolumn{3}{|c|}{ Discharge from Sellafield (Bq/year) } & \multicolumn{2}{|c|}{ Annual rainfall (mm) } \\
\hline & ${ }^{137} \mathrm{Cs}$ & ${ }^{134} \mathrm{Cs}$ & ${ }^{137} \mathrm{Cs}:{ }^{134} \mathrm{Cs}$ & $\begin{array}{c}\text { Western } \\
\text { Isles } \\
\text { (Benbecula) }\end{array}$ & Glasgow \\
\hline 1978 & $4.0 \times 10^{15}$ & $4.0 \times 10^{14}$ & $10 \cdot 3$ & 1166 & 1074 \\
\hline 1979 & $2.6 \times 10^{15}$ & $2.4 \times 10^{14}$ & $10 \cdot 8$ & 1391 & 1133 \\
\hline 1980 & $3.0 \times 10^{15}$ & $2.4 \times 10^{14}$ & $12 \cdot 5$ & 1408 & 1076 \\
\hline 1981 & $2.4 \times 10^{15}$ & $1.7 \times 10^{14}$ & $14 \cdot 1$ & 1488 & 1172 \\
\hline 1982 & $2.0 \times 10^{15}$ & $1.4 \times 10^{14}$ & $14 \cdot 3$ & 1417 & 1182 \\
\hline 1983 & $1.2 \times 10^{15}$ & $8.9 \times 10^{13}$ & $13 \cdot 5$ & 1250 & 1054 \\
\hline 1984 & $4.3 \times 10^{14}$ & $3.5 \times 10^{13}$ & $12 \cdot 3$ & 1376 & 1000 \\
\hline 1985 & $3.3 \times 10^{14}$ & $3.0 \times 10^{13}$ & $11 \cdot 0$ & 1313 & 1178 \\
\hline
\end{tabular}

\section{DIET AND ENVIRONMENT OF ISLANDERS}

North Uist is one of the Outer Hebridean Isles on the north west coast of Scotland (fig 2). It is roughly circular, about $29 \mathrm{~km}$ in diameter, and is bordered by the Atlantic Ocean and the Minch. The island's centre is covered with peat, heather, and coarse grasses and has numerous freshwater lochs. Most islanders live on the narrow fertile strip of coastal grassland on the island's northern, western, and southern sides (the machair) or in the small port Lochmaddy.

Twenty two patients lived on the machair, and most owned sheep and cattle with access to the shore (table III). Nearly all the island's sheep and cattle graze on the machair and some also graze inland during summer and winter. The prevailing winds blow seaspray several kilometres inland. Thus most of the island's inhabitants, livestock, and grasslands are exposed to the sea. 


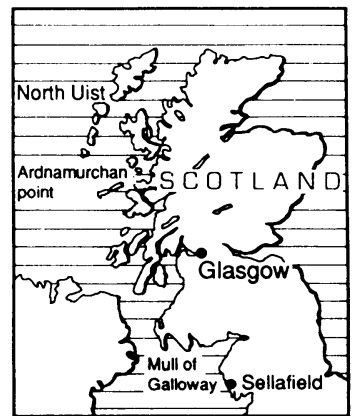

FIG 2-Map of Scotland and North of England
TABLE III - Diet and other characteristics of islanders related to body concentration of ${ }^{137} \mathrm{Cs}$

\begin{tabular}{|c|c|c|c|}
\hline & \multicolumn{3}{|c|}{ Concentration of radiocaesium } \\
\hline & $\begin{array}{l}\text { Top } \\
\text { third }\end{array}$ & $\begin{array}{l}\text { Middle } \\
\text { third }\end{array}$ & $\begin{array}{l}\text { Bottom } \\
\text { third }\end{array}$ \\
\hline No of patients & 11 & 10 & 11 \\
\hline Body ${ }^{17} \mathrm{Cs}(\mathrm{Bq} / \mathrm{gK})$ & $3 \cdot 85-7 \cdot 78$ & $2 \cdot 44-3 \cdot 78$ & $0 \cdot 59-2 \cdot 33$ \\
\hline Live within $400 \mathrm{~m}$ of shore & 9 & 9 & 10 \\
\hline Live on machair & 9 & 6 & 7 \\
\hline $\begin{array}{l}\text { Own sheep and cattle with access to } \\
\text { shore }\end{array}$ & 9 & 7 & 6 \\
\hline $\begin{array}{l}\text { Use seaweed as food, fertiliser, or } \\
\text { livestock feed }\end{array}$ & 10 & 8 & 5 \\
\hline Burn peat on open fire & 10 & 9 & 9 \\
\hline Mean intake local lamb & & & \\
\hline (meals/week) & $2 \cdot 8$ & 1.9 & $2 \cdot 0$ \\
\hline Mean intake local milk (1/week) & $4 \cdot 3$ & 1.5 & $0 \cdot 7$ \\
\hline Mean intake local fish (meals/week) & $1 \cdot 1$ & $1 \cdot 0$ & 1.4 \\
\hline $\begin{array}{l}\text { No eating local vegetables (in } \\
\text { season) }\end{array}$ & 11 & 8 & 8 \\
\hline
\end{tabular}

TABLE IV - Analysis of radiocaesium concentrations by high resolution gamma ray spectrometry

\begin{tabular}{|c|c|c|c|c|c|}
\hline & \multirow{2}{*}{$\begin{array}{c}\text { No of } \\
\text { samples }\end{array}$} & \multicolumn{2}{|c|}{$\begin{array}{l}\text { Median radiocaesium } \\
(\mathrm{Bq} / \mathrm{kg} \text { or } \mathrm{Bq} / \mathrm{l})\end{array}$} & \multirow[b]{2}{*}{${ }^{137} \mathrm{Cs}:{ }^{134} \mathrm{Cs}$} & \multirow[b]{2}{*}{ Range } \\
\hline & & ${ }^{177} \mathrm{Cs}$ & ${ }^{134} \mathrm{Cs}$ & & \\
\hline Uist lamb* & 1 & 92.9 & 0.570 & 164 & - \\
\hline Minch $\operatorname{cod}^{\star}$ & 1 & $23 \cdot 1$ & $0 \cdot 720$ & 32 & - \\
\hline Coastal grasses $†$ & 6 & $21 \cdot 6$ & 0.250 & 86 & $34-192$ \\
\hline Moorland grasses $†$ & 3 & $135 \cdot 9$ & 0.650 & 209 & $200-230$ \\
\hline $\begin{array}{l}\text { Urine from Uist } \\
\text { subjects }\end{array}$ & 12 & $2 \cdot 01$ & 0.013 & 155 & $59-435$ \\
\hline $\begin{array}{l}\text { Urine from mainland } \\
\text { subjects } \ddagger\end{array}$ & 7 & 0.336 & 0.004 & 84 & $36-100$ \\
\hline
\end{tabular}

${ }^{\star}$ Samples chosen because had highest ${ }^{137} \mathrm{Cs}$ concentration. Measured as $\mathrm{Bq} / \mathrm{kg}$ wet weight.

†Caesium measured as $\mathrm{Bq} / \mathrm{kg}$ dry weight

†Five subjects had no detectable ${ }^{14} \mathrm{Cs}$ and have been excluded from analysis. Median value significantly different from that for urine from Uis subjects $(p<0 \cdot 001$ for each isotope)

Islanders often ate locally produced foods, particularly milk, mutton, and potatoes (table III). Patients with the highest concentrations of ${ }^{137} \mathrm{Cs}$ drank more local milk than those with lower concentrations, and there were similar trends for consumption of local lamb and vegetables. Local fish was not an important part of the diet. Indeed the patient with the highest ${ }^{137} \mathrm{Cs}$ concentration ate no fish. One patient in the top third of the range for ${ }^{137} \mathrm{Cs}$ ate venison occasionally, and one patient in the bottom third ate local mushrooms, but otherwise these foods, which sometimes contain high levels of radiocaesium, ${ }^{1718}$ were not a feature of the islanders' diet.

\section{RADIOCAESIUM IN FOOD AND OTHER SAMPLES}

We found ${ }^{137} \mathrm{Cs}$ in all samples analysed. Comparative data were not available for all foods, but in a small number of samples ${ }^{137} \mathrm{Cs}$ concentrations were higher in Uist milk (median $1.6 \mathrm{~Bq} / \mathrm{l} ; \mathrm{n}=4$ ) than in mainland milk $(0.11 \mathrm{~Bq} / \mathrm{l} ; \mathrm{n}=2)$, and in Uist lamb $(16.0 \mathrm{~Bq} / \mathrm{kg})$ $\mathrm{n}=4)$ than in mainland lamb $(13 \cdot 1 \mathrm{~Bq} / \mathrm{kg} ; \mathrm{n}=2)$. The ${ }^{137} \mathrm{Cs}$ concentration of Minch fish $(20.8 \mathrm{~Bq} / \mathrm{kg} ; \mathrm{n}=4)$ was greater than that of fish from the North Sea $(7 \cdot 8 \mathrm{~Bq} / \mathrm{kg} ; \mathrm{n}=3) .{ }^{22}$ High ${ }^{137} \mathrm{Cs}$ concentrations were also found in seaweed $(31.9 \mathrm{~Bq} / \mathrm{kg} ; \mathrm{n}=2)$, sand $(11.0 \mathrm{~Bq} / \mathrm{kg} ; \mathrm{n}=3)$, and peat $(4 \cdot 0 \mathrm{~Bq} / \mathrm{kg} ; \mathrm{n}=6)$ from North Uist.

Using these data and assuming a half life of ${ }^{137} \mathrm{Cs}$ of 110 days we calculate by first order kinetics that an islander whose regular weekly intake included $0.6 \mathrm{~kg}$ local lamb, 41 (7 pints) local milk, $0.2 \mathrm{~kg}$ local fish and $1.4 \mathrm{~kg}$ local potatoes would have a ${ }^{137} \mathrm{Cs}$ concentration around $2 \cdot 1 \mathrm{~Bq} / \mathrm{gK}$, with lamb and milk contributing most of this. The patient with the highest body concentration in North Uist $(7.78 \mathrm{~Bq} / \mathrm{gK})$ lived $50 \mathrm{~m}$ from the Minch coast at the southernmost part of the island and owned sheep and cattle with access to the shore and to inland grasses; ${ }^{137} \mathrm{Cs}$ concentrations in the meat from his sheep $(92.9 \mathrm{~Bq} / \mathrm{kg})$ and in milk $(2.8 \mathrm{~Bq} / \mathrm{l})$, seaweed $(37.2 \mathrm{~Bq} / \mathrm{kg})$, sand $(12.5 \mathrm{~Bq} / \mathrm{kg})$, and peat $(4.6 \mathrm{~Bq} / \mathrm{kg})$ from his farm were the highest we found on the island. He claimed that he ate meat from his sheep four to six times a week, drank 21 (3.5 pints) of home produced milk weekly but never ate fish. The concentration of ${ }^{137} \mathrm{Cs}$ in his lamb and milk would be sufficient to maintain his observed body content of ${ }^{137} \mathrm{Cs}$.

We detected ${ }^{137} \mathrm{Cs}$ in all and ${ }^{134} \mathrm{Cs}$ in most of the samples analysed by high resolution gamma ray spectrometry (table IV). ${ }^{134} \mathrm{Cs}$ was found in Uist lamb and Minch cod, but was not detected in island or mainland milk. The Uist herbage samples all contained measurable amounts of ${ }^{134} \mathrm{Cs}$, the ratio of ${ }^{137} \mathrm{Cs}$ to ${ }^{134} \mathrm{Cs}$ for the moorland sites (209) being greater than that observed in coastal grasses $(86) .{ }^{134} \mathrm{Cs}$ was found in the urine of all islanders tested and in seven of 12 Glasgow controls, the other five controls having low urinary ${ }^{137} \mathrm{Cs}$ concentrations (table IV). The urinary ${ }^{137} \mathrm{Cs}$ concentration in islanders (median $2.01 \mathrm{~Bq} / \mathrm{l}$ ) was six times higher than that in Glasgow controls $(0.336 \mathrm{~Bq} / \mathrm{l})$, a similar excess to that of total body ${ }^{137} \mathrm{Cs}$ concentrations.

\section{Discussion}

Before the Chernobyl accident in 1986 most ${ }^{137} \mathrm{Cs}$ in humans had been assumed to be derived from the 을 atmospheric testing of nuclear weapons; ${ }^{137} \mathrm{Cs}$ fallout is carried to earth in rain and taken up by plants, thereby entering the human food chain. Milk and meat are the principal sources, together accounting for $60-80 \%$ of total intake. ${ }^{1}$

Our study confirms a preliminary report that patients from the Western Isles have higher body ${ }^{137} \mathrm{Cs}$ concentrations than do patients from the Scottish mainland. ${ }^{3}$ Values similar to those found in island patients were recorded at Harwell, Oxfordshire, in 1964, after atmospheric weapons testing during $1961-2,{ }^{16}$ and values 100 times higher were found in Alaska and Finland, also in $1964 .{ }^{19}$

We measured body ${ }^{137} \mathrm{Cs}$ concentrations in islanders with hypertension but found no evidence (apart from in hyperaldosteronism) that ${ }^{137} \mathrm{Cs}$ concentrations differed in patients with different types of hypertension or in patients with diseases other than hypertension (table I). Because the principal determinant of body ${ }^{137} \mathrm{Cs}$ is dietary intake our results suggest that islanders consume more ${ }^{137} \mathrm{Cs}$ than do people on the mainland.

We considered three explanations for increased ${ }^{137} \mathrm{Cs}$ concentrations in islanders. Firstly, higher rainfall 옥 over the islands may produce greater fallout. Figures $N$ from the Meteorological Office, however, indicate that during $1978-85$ rainfall was only marginally higher in the Western Isles than in the Glasgow area (table II).

The second possibility is that fallout is the same but that conditions on the island provide greater than usual $\omega$ transfer of isotope to the islanders' diet. For example, island milk may contain more ${ }^{137} \mathrm{Cs}$ than mainland milk 0 because Uist cattle graze on peat based grasses and $\mathbb{D}$ plants grown on peat take up more radiocaesium than do those on clay based soils..$^{20}$ Sediments of lochs may also retain and slowly release ${ }^{137} \mathrm{Cs},{ }^{21}$ which could also lead to increased ${ }^{137} \mathrm{Cs}$ concentrations in milk. Thus $\stackrel{\odot}{\mathscr{\Omega}}$ high body ${ }^{137} \mathrm{Cs}$ in islanders might be explained by $\stackrel{\mathbb{Q}}{2}$ unusually prolonged retention and release of ${ }^{137} \mathrm{Cs}$ 穴 deposited in the 1960s when fallout was greater. Such $ᄋ$ mechanisms have resulted in foodchains capable of concentrating radiocaesium up to one hundred fold. ${ }^{17}$

The third possibility is that the excess ${ }^{137} \mathrm{Cs}$ comes from waste discharged into the sea by Sellafield, which is the main source of ${ }^{137} \mathrm{Cs}$ in British coastal waters. ${ }^{22}$ ${ }^{137} \mathrm{Cs}$ discharged into the sea has been shown to be taken up by west Cumbrian coastal grasses, ${ }^{23}$ and sheep and 
cattle consuming these grasses have much higher ${ }^{137} \mathrm{Cs}$ concentrations. ${ }^{24}{ }^{25}$ The concentration of ${ }^{137} \mathrm{Cs}$ in seawater around the Western Isles is higher than that in other British seas because discharges from Sellafield are carried northwards up the west coast by gulf stream currents. ${ }^{26}$ Dilution of the isotope by lateral movement of water is reduced to the east by the coast and to the west by the Outer Hebridean Islands and onshore westerly winds. From the Mull of Galloway to Ardnamurchan Point at the entrance to the Minch the ${ }^{137} \mathrm{Cs}$ concentration in seawater is diluted less than five times after a journey of $240 \mathrm{~km}$. ${ }^{26}$

The best evidence that Sellafield is an important source of radioactive caesium in the Western Isles is the finding of ${ }^{144} \mathrm{Cs}$ in most of the samples analysed. ${ }^{134} \mathrm{Cs}$ is produced by reprocessing nuclear fuels ${ }^{22}$ but not by explosion of nuclear weapons, ${ }^{27}$ and thus finding ${ }^{134} \mathrm{Cs}$ confirms reprocessing as the ultimate source.

Further information on the ultimate source and food chain may be derived from an analysis of the ratio of ${ }^{137} \mathrm{Cs}$ to ${ }^{134} \mathrm{Cs}$. If Sellafield is the source the ratio in different samples along the chain should be higher than that of the discharge, partly because ${ }^{134} \mathrm{Cs}$ has a shorter half life than ${ }^{137} \mathrm{Cs}$, and partly because ${ }^{137} \mathrm{Cs}$ will be added from bomb fallout. We found ratios of ${ }^{137} \mathrm{Cs}:{ }^{134}$ ranging from 34 to 435 , all higher than ratio of discharges from Sellafield (11:1 in 1985). ${ }^{15}$ Our studies would have benefited from more samples, but this was prevented by the Chernobyl nuclear accident. Moorland vegetation showed the greatest radiocaesium concentration and highest ${ }^{137} \mathrm{Cs}:{ }^{134} \mathrm{Cs}$ ratio (209). The richer coastal soils, which are constantly influenced by seawater showed a lower radiocaesium concentration and ${ }^{137} \mathrm{Cs}:{ }^{134} \mathrm{Cs}$ ratio $(86)$. Locally produced lamb $(164)$ and islanders' urine (155) showed intermediate ratios, suggesting similar contributions derived from both types of vegetation.

Unexpectedly we found ${ }^{134} \mathrm{Cs}$ in the urine of seven Glasgow control subjects. We do not know the exact sources of milk and lamb consumed by Glaswegians, but it traditionally comes from south west Scotland and not from the Western Isles. Some of these southern farms are coastal and closer to Sellafield than is North Uist. Thus, radiocaesium from Sellafield could also enter the food chain of Scottish mainlanders. A recent description of increased body radiocaesium concentrations in a Japanese family during a visit to Britain supports these findings. Togo et al argued that the Japanese food chain would have a radiocaesium component from fall out similar to that in Britain, and attributed the increased concentrations to discharges from Sellafield. ${ }^{28}$

The amount of additional radioactivity to which our patients were exposed is small. Taking the whole body radiation dose to adults as $5.4 \mu \mathrm{Sv}$ a year for every $1 \mathrm{~Bq} / \mathrm{gK}$ of ${ }^{137} \mathrm{Cs},{ }^{1}$ the average islander would be exposed to only $13.7 \mu \mathrm{Sv}$ a year from ${ }^{137} \mathrm{Cs}$, which is much less than the current recommended limit for exposure to members of the public of $1000 \mu \mathrm{Sv}$ a year, including $500 \mu \mathrm{Sv}$ a year from discharges from a single site. ${ }^{29}$ Moreover, exposure at $13.7 \mu \mathrm{Sv}$ a year represents only a $7 \%$ increase in the radiation already received from the body's naturally occurring ${ }^{40} \mathrm{~K}$ ( $200 \mu \mathrm{Sv} /$ year), which is itself only a small fraction of the total radiation received from all natural sources, currently estimated to be $2500 \mu \mathrm{Sv}$ a year in Britain. ${ }^{30}$

In conclusion, inhabitants of the Western Isles have raised body radiocaesium concentrations. The immediate source is excess dietary intake of isotope. The presence of ${ }^{134} \mathrm{Cs}$ in the food chain and in the urine of western islanders indicates that at least part of the excess comes from discharges of radiocaesium from Sellafield reprocessing plant. Although the radiation risk is small it is important to record that an isotope discharged into the sea as waste may return to land at a considerable distance from the site of discharge and enter the human food chain.

We thank Miss Anne Matheson and Mrs Josephinew Campbell for secretarial help, and Mrs Ruby Watt and Mrs? Gillian Davidson for technical help.

1 National Council on Radiation Protection and Measurements. Caesium-137 from the environment to man: metabolism and dose. Washington: NRCP, 1977 . (NRCP Report No 52.)

2 Rundo J. A survey of the metabolism of caesium in man. Br $f$ Radio 1964;37:108-14.

Williams DE, Harvey IR, Haywood JK, McArdle FJ. Whole body caesium137 levels in man in Scotland, 1978-1979. Health Phys 1981;40:1-4.

4 Newton D, Tyler GR. Caesium-137 levels in residents of the Scottish mainland and Hebrides. Health Phys 1982;42:735-7.

5 Isles CG, Robertson I, Brown IJ, et al. Measurements of 137-caesium levels in $\vec{\circ}$ residents of Western Scotland. Clin Sci 1983;64:3-4P.

6 East BW, Preston T, Robertson I. Monitoring the population for 137-caesium $\vec{\omega}$ and 134-caesium contamination. In: Myttenaere C, ed. Seminar on the environmental transfer to man of radionuclides released from nuclear installations. Vol 2. Luxembourg: Commission of the European Communities, 1984:3 541.54.

7 Beretta-Piccoli C, Davies DL, Boddy K, et al. Relation of arterial pressure with body sodium, body potassium and plasma potassium in essential? hypertension. Clin Sci 1982;63:257-70.

8 Williams ED, Boddy K, Brown JJ, et al. Whole body elemental composition in patients with essential hypertension. Eur f C Clin Invest 1982;12:321-5.

9 Boddy K, Elliot A, Robertson I, Mahaffy ME, Holloway I. A high sensitivitydual-detector shadow-shield whole body counter with an invariant response for total body in vivo neutron activation analysis. Phys Med Biol 1975;20: 296-304.

10 Boddy K, King PC, Tothill P, Strong JA. Measurement of total body potassium with a shadow shield whole body counter: calibration and errors. N
Phys Med Biol 1971;16:275-82.

11 Agricultural Research Council Radiobiological Laboratory. Annual report 1965-1966. Letcombe, Oxfordshire: ARCL 1966. (Report No 16.)

12 Hunt GJ. Radioactivity in surface and coastal waters of the British Isles 1984. (D) Aquatic environment monitoring report. Lowestoft: Ministry of Agriculture, Fisheries and Food, 1985.

13 Prout WE, Russell ER, Groh HJ. Ion exchange absorption of caesium by potassium hexacyanocobalt (II) ferrate (II). Fournal of Inorganic Nuclear' Chemistry 1965;27:473-9.

14 Boni AL. Rapid ion exchange analysis of radiocaesium in milk, urine, seawater and environmental samples. Analytical Chemistry 1966;38:89-92.

5 Stather JW, Wrixon AD, Simmonds JR. The risk of leukaemia and other cancers in Seascale from radiation sources. Harwell: National Radiological Protection Board, 1984. (NRPB Report R171.)

16 Newton D, Eagle MC, Venn JB. The caesium-137 content of man related to fallout in rain, 1957-1976. International fournal of Environmental Studies $\Rightarrow$ 1977;11:83-90

17 Hanson WC. Caesium-137 in Alaskan lichens, caribou and eskimos.马 Health Phys 1987:13:383-9.

18 Grueter $\mathrm{H}$. Radioactive fission product 137 caesium in mushrooms in West Germany during 1963-1970. Health Phys 1971;20:655-6.

19 United Nations Scientific Committee on the Effects of Atomic Radiation. Sources and effects of ionising radiation. New York: United Nations, 1977.

20 Cawse PA. The accumulation of caesium 137 and plutonium 239 and 240 in soils of Great Britain, and transfer to vegetation. In: Coughtrey PJ, Bell JN; Roberts TM, eds. Ecological Aspects of Radionuclide Release. Oxford: Blackwell Scientific, 1983. (Special publications series of the British Ecological Society No 3 .)

21 Comans RNJ, Middelburg JJ, Zonderhuis J, et al. Mobilisation of radio caesium in pore water of lake sediments. Nature 1989;339:367-9.

22 Hunt GJ. Radioactivity in surface and coastal waters of the British Isles 1988.0 Aquatic environment monuoring report. Lowestoft: Ministry of Agriculture, Fisheries, and Food, 1989.

23 Bradford WR, Curtis EJC, Popplewell DS. Radioactivity in environmenta samples taken in Sellafield and Ravenglass areas of west Cumbria 1977-1982 I The Science of the Total Environment 1984;35:267-83.

24 Popplewell DS, Ham GJ, Savory TE, Bradford WR. Radionuclide concentra tions in some cattle and sheep from west Cumbria. Radiological Protection tions in some cattle and sheep from west Cumbria. Radiological Protection

25 Howard BJ. Aspects of the uptake of radionuclides by sheep grazing on an $\omega$ estuarine salt marsh. 1. The influence of grazing behaviour and environ mental variability on daily intake. Fournal of Environmental Radioactivity 1985;2:183-98.

26 Jeffries DF, Steele AK, Preston A. Further studies on the distribution of 137-caesium in British coastal water. I. Irish Sea. Deep Sea Research 1982;29:713-38.

27 MacKenzie AB, Baxter MS, McKinley IG, Swan DS, Jack W. The determination of 134-caesium, 137-caesium, ${ }^{210} \mathrm{~Pb},{ }^{226} \mathrm{Rs}$ and ${ }^{22 x} \mathrm{Ra}$ concen-O trations in near-shore marine sediments and sea water. Joumal of Radioanalytical Chemistry 1979:48:29-47.

28 Togo M, Anzai I, Togo T 137-Caesium deposition in Japanese temporary residents of England. Healeh Phys 1983,45:162.

29 Consequences of the new radiation dosimetry [editorial]. Lancet 1987;ir

1245-7.
30 Clarke RH, Southwood TRE. Risks from ionising radiation. Nature 1989;338. $197-8$

(Accepted 25 April 1991)

\section{列}

,

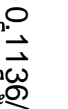

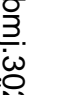

$$
\text { o }
$$

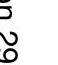

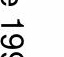

$$
\text { 象 }
$$

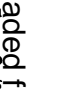

